\title{
Combined effects of ocean acidification and hypoxia on the early development of the thick shell mussel Mytilus coruscus
}

\author{
Xinghuo Wang ${ }^{1,2,3 \dagger}$, Yueyong Shang ${ }^{1,2,3 \dagger}$, Hui Kong ${ }^{1,2,3}$, Menghong Hu ${ }^{1,2,3}$, Jinlong Yang ${ }^{2,3}$, Yuewen Deng ${ }^{\text {* }}$ \\ and Youji Wang ${ }^{1,2,3^{*}}$ (D)
}

\begin{abstract}
Ocean acidification has become serious, and seawater hypoxia has become evident in acidified waters. The combination of such stressors may have interactive effects on the fitness of marine organisms. In order to investigate the interactive effects of seawater acidification and hypoxia on the early development of marine bivalves, the eggs and sperm of the thick shell mussel Mytilus coruscus were exposed to combined treatments of $\mathrm{pH}(8.1,7.7,7.3)$ and dissolved oxygen (2, $6 \mathrm{mg} / \mathrm{L})$ for $96 \mathrm{~h}$ culture observation to investigate the interactive effects of seawater acidification and hypoxia on the early development of marine bivalves. Results showed that acidification and hypoxia had significant negative effects on various parameters of the early development of the thick shell mussel. However, hypoxia had no effect on fertilization rate. Significant interactions between acidification and hypoxia were observed during the experiment. Short-term exposure negatively influenced the early development of the thick shell mussel but did not affect its survival. The effects of long-term exposure to these two environmental stresses need further study.
\end{abstract}

Keywords: Ocean acidification, Hypoxia, Mytilus coruscus, Early development

\section{Background}

Ocean Acidification (OA), i.e., a decrease in seawater $\mathrm{pH}$ (increased acidity) associated with a change in carbonate equilibrium system, is a consequence of the large amount of anthropogenic $\mathrm{CO}_{2}$ absorbed by the ocean [1-3]. The current surface seawater $\mathrm{pH}$ is approximately $8.1-8.2$ and is predicted to decrease to $7.7-7.8$ by 2100 and $7.3-7.4$ by $2300[4,5]$. OA can affect the fertilization [6], embryonic development, metabolism [7], behavior [8-10], and immunity [11] of various marine organisms; threatens the survival and reproduction of marine animals; and damages global marine biodiversity and ecosystem stability [12-15]. Acidification negatively affects the early

\footnotetext{
*Correspondence: dengyw@gdou.edu.cn; youjiwang2@gmail.com ${ }^{\dagger}$ Xinghuo Wang and Yueyong Shang contributed equally to this work ${ }^{1}$ Fisheries College, Guangdong Ocean University, Zhanjiang 524088, China

Full list of author information is available at the end of the article
}

developmental stage of abalones Haliotis diversicolor and significantly reduces the survival rate of larvae [16]. In addition, low pH delays the development of mussel Mytilus galloprovincialis larvae [17].

Seawater acidification does not occur alone in the natural environment. Other stressors, such as hypoxia, also affect the marine environment [18-22]. Hypoxia are areas with hypoxic conditions that the dissolved oxygen (DO) concentration in the water is $<2.0 \mathrm{mg} / \mathrm{L} \mathrm{[23].}$ $\mathrm{OA}$ is likely to occur in areas where the seawater is deficient in oxygen $[24,25]$. The decrease in seawater DO can enhance seawater acidification, and the seawater $\mathrm{pH}$ decreases with the value of DO [19]. Low DO in water negatively influences marine organisms and even threatens the survival of marine life [26-28]. Clark and Gobler [29] found that low DO inhibits the development and significantly reduces the survival rate of bay scallop Argopecten irradians larvae $(2.33 \mathrm{mg} / \mathrm{L})$.

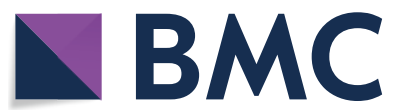

c) The Author(s) 2020. This article is licensed under a Creative Commons Attribution 4.0 International License, which permits use, sharing, adaptation, distribution and reproduction in any medium or format, as long as you give appropriate credit to the original author(s) and the source, provide a link to the Creative Commons licence, and indicate if changes were made. The images or other third party material in this article are included in the article's Creative Commons licence, unless indicated otherwise in a credit line to the material. If material is not included in the article's Creative Commons licence and your intended use is not permitted by statutory regulation or exceeds the permitted use, you will need to obtain permission directly from the copyright holder. To view a copy of this licence, visit http://creativecommons.org/licenses/by/4.0/. 
Marine mussels have become a popular model animal in marine environmental monitoring research owing to their relatively long lifespan, sessile benthic life style, filter feeding, bioaccumulation capability in body, and global distribution [30]. Embryonic and early larval developments are important stages of mollusk life cycle. Benthic animals experience stress, such as nutrition deficiency, pollution and infiltration, and growth inhibition during larval stage [31]. Early embryos and larvae of shellfish are sensitive to environmental disturbances. OA exposure of oysters during early development can potentially inhibit their subsequent growth and development [32]. Stevens and Gobler [33] studied the effects of ocean acidification and hypoxia on bay scallop Argopecten irradians and found that acidification significantly reduces their survival rate, and this effect is further aggravated by hypoxia. Gobler et al. [34] analyzed the effects of ocean acidification and hypoxia on the early development of hard clams Mercenaria mercenaria and found that acidification significantly inhibits larval growth, and hypoxia intensifies this influence. Considering that acidification and hypoxia exist simultaneously in actual marine ecosystems, the effects of complex ecological effects of acidification and hypoxia on marine organisms must be investigated. Exploring this aspect can further clarify the mechanism underlying acidification and hypoxia on marine organisms and help to assess the impact of environmental variability on coastal organisms.

Mussels are the key components of marine intertidal ecosystems and enhance the coastal diversity [35]. The thick shell mussel Mytilus coruscus is one of the most important aquaculture shellfish and possesses important economic value in China [36]. Heavy mortalities of mussels have occurred frequently during summer in the Shengsi island probably due to hypoxia and low $\mathrm{pH}$ conditions [37]. At present, the interactive effect of ocean acidification and hypoxia on the early development of $M$. coruscus is still unclear. We hypothesize that the early development of mussels is seriously affected by acidification and hypoxia, and these effects are aggravated when both stressors appear simultaneously. The eggs and sperm of the thick shell mussel were exposed to six treatments [three pH levels (8.1, 7.7, and 7.3) and two DO levels ( 2 and $6 \mathrm{mg} \mathrm{O}_{2} / \mathrm{L}$ )] for $96 \mathrm{~h}$ culture observation to study the combined effects of ocean acidification and hypoxia on the early development of this species. Fertilization rate, cleavage rate, deformity rate, larval shell length, and shell height were also evaluated.

\section{Materials and methods}

\section{Experimental animals}

Mussels (shell length $8.0 \pm 2.0 \mathrm{~cm}$, dry weight $1.60 \pm 0.90 \mathrm{mg}$ ) were collected from the Shengsi Island,
Zhejiang Province, China. After cleaning, the mussels were acclimated in the aquarium for a week. Temperature, salinity, and DO were controlled at $20.0 \pm 0.3{ }^{\circ} \mathrm{C}$, $25.0 \pm 0.5$, and $6.0 \pm 0.3 \mathrm{mg} \mathrm{O}_{2} / \mathrm{L}$, respectively. Water was completely changed once a day, and dead mussels were removed during acclimation. Isochrysis galbana $\left(2.5 \times 10^{4}\right.$ cells $\left./ \mathrm{mL}\right)$ was fed to mussels daily. After 1 -week acclimation, 60 parental mussels ( 45 females, 15 males) were stimulated with flowing filtered seawater for $10 \mathrm{~min}$ before spawning and then transferred to a $60 \mathrm{~L}$ spawning tank. Thermal shock method was applied by rapidly increasing the water temperature from 13 to $23{ }^{\circ} \mathrm{C}$ to achieve large-scale spawning $[38,39]$. Male mussels that release sperm and female mussels that spawn were transferred to two $30 \mathrm{~L}$ spawning tanks for ejaculation and spawning, respectively. After ejaculation and spawning, $15 \mathrm{~mL}$ of seawater containing eggs (density of about $2 \times 10^{3} / \mathrm{mL}$ ) and $15 \mathrm{~mL}$ of seawater containing sperm (density of about $1 \times 10^{6} / \mathrm{mL}$ ) were sampled and transferred to aquariums $(30 \mathrm{~L})$ with different $\mathrm{pH}$ and DO levels for fertilization.

\section{Experimental design}

Six experimental treatments (1) $\mathrm{pH} 8.1 \times 6 \mathrm{mg} \mathrm{O}_{2} / \mathrm{L}$, (2) $\mathrm{pH} 8.1 \times 2 \mathrm{mg} \mathrm{O}_{2} / \mathrm{L}$, (3) $\mathrm{pH} 7.7 \times 6 \mathrm{mg} \mathrm{O}_{2} / \mathrm{L}$, (4) $\mathrm{pH}$ $7.7 \times 2 \mathrm{mg} \mathrm{O}_{2} / \mathrm{L}$, (5) $\mathrm{pH} 7.3 \times 6 \mathrm{mg} \mathrm{O} / \mathrm{L}$, and (6) $\mathrm{pH}$ $7.3 \times 2 \mathrm{mg} \mathrm{O}_{2} / \mathrm{L}$ ) and three replicates were set for each treatment. Exposure lasted for 4 days, and the development of fertilized eggs was investigated and recorded at $2,4,8,24,48,72$, and $96 \mathrm{~h}$.

The $\mathrm{pH}$ in the experimental aquarium was controlled by using a $\mathrm{pCO}_{2} / \mathrm{pH}$ system (DAQ-M) equipped with a WTW pH $3310 \mathrm{~m}$ and a SenTix $41 \mathrm{pH}$ electrode (Loligo Systems Inc., Denmark) [40]. Low pH treatment was achieved by aerating $\mathrm{CO}_{2}$ into the seawater by this $\mathrm{pCO}_{2} /$ $\mathrm{pH}$ system. Either $\mathrm{N}_{2}$ or air was passed through the $\mathrm{O}_{2}$ regulator (Loligo Systems Inc., Denmark) into the seawater to achieve the hypoxic conditions [41].

\section{Seawater chemical parameters}

Seawater parameters were monitored daily. Total alkalinity (AT) was determined by titration. Temperature, salinity, and DO were measured using a multi-parameter water quality instrument (5200A, YSI Inc., America). pH was detected by a pH meter (pH-201, MSITECH (AsiaPacific) Pte. Ltd., Singapore). Other chemical parameters [dissolved inorganic carbon (DIC), $\mathrm{pCO}_{2}$, calcite saturation state $(\Omega \mathrm{cal})$, and aragonite saturation state ( $\Omega \mathrm{ara})]$ were calculated by $\mathrm{CO}_{2}$ SYS [42].

\section{Biological parameters}

After $2 \mathrm{~h}$ of fertilization, the egg samples were observed by a microscope fitted with an ocular micrometer, and 
fertilization was evaluated by the presence of polar body and embryonic cleavage $[38,39]$. The egg samples were obtained $4 \mathrm{~h}$ after fertilization, and cleavage was assessed by observing embryonic morphology at 48, 72, and $96 \mathrm{~h}$ to assess embryo deformity. Malformations observed in the study of Kong et al. were used as evaluation criteria [15]. For the deformity, embryos were visually inspected and characterized as slightly deformed, broken, and deformed during embryonic division (Fig. 1). During sampling, 100 eggs were randomly selected from each aquarium, and fertilization rate, deformity rate, and cleavage rate were calculated after observation. At 48, 72, and 96 h, 50 D-shaped larvae were randomly obtained from each aquarium, and their shell length and height were measured by a microscope fitted with an ocular micrometer (Nikon Eclipse 55i, Japan).

\section{Statistical analysis}

Data analysis was performed by SPSS 19.0 software, and percentage data were arcsine square root transformed prior to analysis. Experimental data were tested for homogeneity of variance and normal distribution. Threeway ANOVA was used to assess whether the interaction among $\mathrm{pH}, \mathrm{DO}$, and time affects the deformation rate of the fertilized eggs of the thick shell mussel. Two-way
ANOVA was employed to analyze whether the interaction between $\mathrm{pH}$ and DO influences the fertilization rate, cleavage rate, and shell length and height of the thick shell mussel. Tukey post hoc tests were performed for the effects of $\mathrm{pH}$ and $\mathrm{DO}$, respectively, with $\mathrm{p}<0.05$ as a criterion for significant difference.

\section{Results}

The $\mathrm{pH}$ of each treatment was stably maintained within the required levels by using the $\mathrm{pH} / \mathrm{pCO}_{2}$ control system. Salinity and temperature were maintained at approximately 25 and $20{ }^{\circ} \mathrm{C}$, respectively, during the whole experiment. The seawater chemical parameters of each experimental group are shown in Table 1.

The fertilization rate of mussel gametes was only significantly affected by $\mathrm{pH}(\mathrm{P}<0.05)$ (Table 2, Fig. 2). At DO of $6 \mathrm{mg} / \mathrm{L}$, the fertilization rate under $\mathrm{pH} 7.3$ was significantly lower (decreased by $14.7 \%$ ) than that under $\mathrm{pH} 8.1(\mathrm{P}<0.05)$. No significant difference was observed between $\mathrm{pH} 8.1$ and $\mathrm{pH} 7.7$ and between $\mathrm{pH} 7.7$ and $\mathrm{pH}$ 7.3. At the $\mathrm{DO}$ of $2 \mathrm{mg} / \mathrm{L}$, the fertilization rate under $\mathrm{pH}$ 7.3 was significantly lower than that under $\mathrm{pH} 8.1$ and 7.7 $(\mathrm{P}<0.05)$.

The cleavage rate was significantly affected by $\mathrm{pH}$ and DO $(\mathrm{P}<0.05)($ Fig. 3$)$, and a significant interaction was

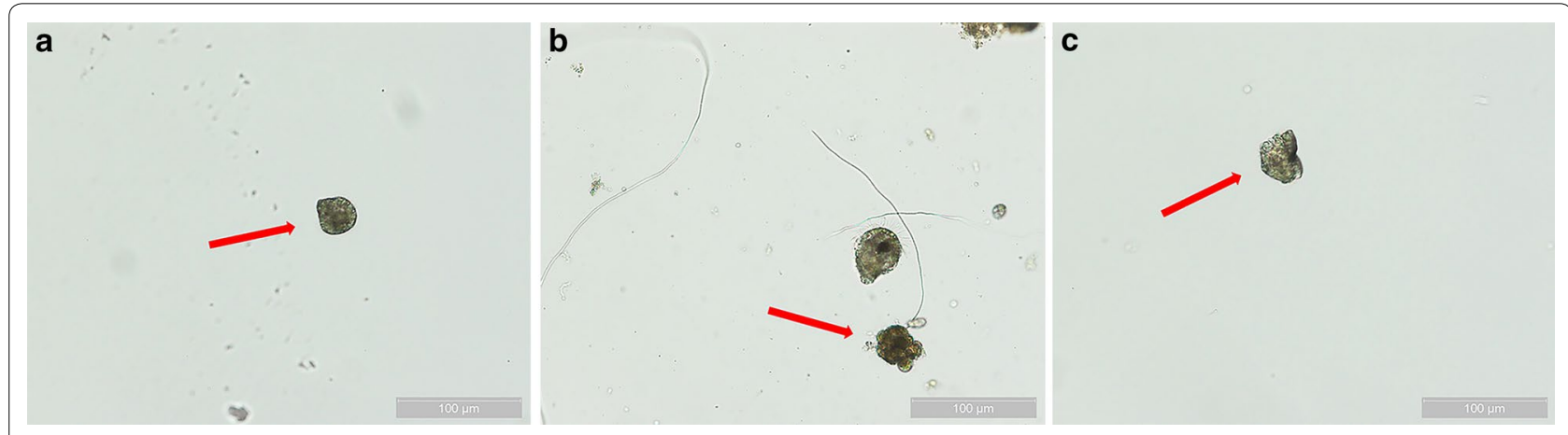

Fig. 1 The categorization of deformity of embryos. a Slightly deformed of the embryo; $\mathbf{b}$ deformity during embryonic division; c embryo breakage

Table 1 Seawater chemistry parameters during the experiment (mean \pm SD)

\begin{tabular}{lllllllll}
\hline $\mathbf{D O}(\mathbf{m g} / \mathbf{L})$ & $\mathbf{p H}_{\mathbf{N B S}}$ & Salinity & $\mathbf{T}\left({ }^{\circ} \mathbf{C}\right)$ & $\mathbf{T}_{\mathbf{A}}(\boldsymbol{\mu m o l} / \mathbf{k g})$ & $\mathbf{D I C}(\boldsymbol{\mu m o l} / \mathbf{k g})$ & $\mathbf{p c o}_{\mathbf{2}}(\boldsymbol{\mu a t m})$ & $\mathbf{\Omega} \mathbf{c a l}$ & $\Omega \mathbf{a r a}$ \\
\hline $6.1 \pm 0.1$ & $7.33 \pm 0.03$ & $25.1 \pm 0.1$ & $20.0 \pm 0.1$ & $2316 \pm 11$ & $2343 \pm 22$ & $2715 \pm 23$ & $1.04 \pm 0.08$ & $1.19 \pm 0.05$ \\
$2.0 \pm 0.2$ & $7.30 \pm 0.01$ & $25.2 \pm 0.1$ & $20.1 \pm 0.2$ & $2345 \pm 28$ & $2379 \pm 32$ & $2939 \pm 18$ & $1.01 \pm 0.03$ & $1.22 \pm 0.01$ \\
$6.0 \pm 0.1$ & $7.69 \pm 0.02$ & $25.1 \pm 0.3$ & $20.0 \pm 0.2$ & $2376 \pm 11$ & $2224 \pm 19$ & $1015 \pm 10$ & $1.77 \pm 0.04$ & $1.24 \pm 0.06$ \\
$2.0 \pm 0.2$ & $7.70 \pm 0.01$ & $25.1 \pm 0.2$ & $20.0 \pm 0.1$ & $2295 \pm 39$ & $2114 \pm 15$ & $995 \pm 11$ & $1.84 \pm 0.17$ & $1.19 \pm 0.03$ \\
$6.1 \pm 0.1$ & $8.09 \pm 0.02$ & $25.0 \pm 0.1$ & $19.9 \pm 0.2$ & $2241 \pm 41$ & $1994 \pm 19$ & $351 \pm 21$ & $4.39 \pm 0.07$ & $2.76 \pm 0.09$ \\
$2.1 \pm 0.1$ & $8.10 \pm 0.02$ & $25.0 \pm 0.1$ & $20.0 \pm 0.1$ & $2208 \pm 20$ & $2059 \pm 31$ & $373 \pm 12$ & $4.40 \pm 0.10$ & $2.91 \pm 0.07$ \\
\hline
\end{tabular}

$\mathrm{pH}$ was monitored by the $\mathrm{pH} / \mathrm{CO}_{2}$ system continuously during the experiment. Salinity, temperature and total alkalinity $\left(\mathrm{T}_{\mathrm{A}}\right)$ were determined at each sampling time $(n=5)$. Dissolved inorganic carbon (DIC), partial pressure of $\mathrm{CO}_{2}\left(\mathrm{pCO}_{2}\right)$, saturation degrees for calcite $(\Omega$ cal) and aragonite $(\Omega$ ara) were calculated based on the above parameters 
Table 2 Summary of two-way ANOVA results on effects of $\mathrm{pH}$ and DO on fertilization rate and cleavage rate

\begin{tabular}{|c|c|c|c|c|c|c|}
\hline & & SS & df & MS & $F$ & $P$ \\
\hline \multirow{5}{*}{$2 \mathrm{~h}$ fertilization rate } & $\mathrm{DO}$ & 80.222 & 1 & 80.222 & 2.911 & 0.114 \\
\hline & $\mathrm{pH}$ & 837.444 & 2 & 418.722 & 15.196 & 0.001 \\
\hline & $\mathrm{DO} * \mathrm{pH}$ & 58.111 & 2 & 29.056 & 1.054 & 0.379 \\
\hline & Error & 330.667 & 12 & 27.556 & & \\
\hline & Total & 96064.000 & 18 & & & \\
\hline \multirow[t]{5}{*}{4 h cleavage rate } & DO & 760.500 & 1 & 760.500 & 63.967 & 0.000 \\
\hline & $\mathrm{pH}$ & 1477.000 & 2 & 738.500 & 62.117 & 0.000 \\
\hline & $\mathrm{DO} * \mathrm{pH}$ & 394.333 & 2 & 197.167 & 16.584 & 0.000 \\
\hline & Error & 142.667 & 12 & 11.889 & & \\
\hline & Total & 8935.000 & 18 & & & \\
\hline
\end{tabular}

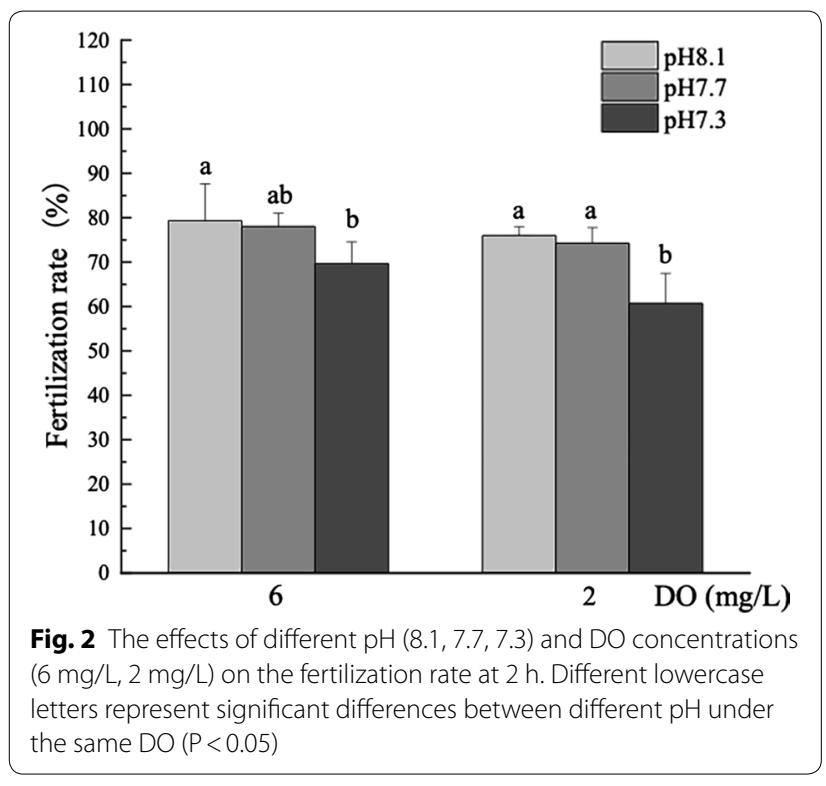

found between $\mathrm{pH}$ and $\mathrm{DO}(\mathrm{P}<0.05)$ (Table 2). At DO of $6 \mathrm{mg} / \mathrm{L}$, the cleavage rate of mussel decreased significantly with the $\mathrm{pH}(\mathrm{P}<0.05)$. At $\mathrm{DO}$ of $2 \mathrm{mg} / \mathrm{L}$, the cleavage rate of mussels under acidification $(\mathrm{pH} 7.7$ and $\mathrm{pH} 7.3)$ was significantly reduced $(\mathrm{P}<0.05)$. At low $\mathrm{DO}$, the cleavage rate decreased significantly under $\mathrm{pH} 8.1$ and $7.7(\mathrm{P}<0.05)$.

The deformation rate of mussels was significantly affected by time, $\mathrm{DO}$, and $\mathrm{pH}(\mathrm{P}<0.05)$ (Table 3$)$, but these factors did not have significant interactions. When the fertilized eggs were exposed for 48, 72, and $96 \mathrm{~h}$, the deformity rate increased significantly $(\mathrm{P}<0.05)$ with the decrease in $\mathrm{pH}$ under the two DO conditions (Fig. 4). With prolonged exposure time, the deformation rate increased significantly at DO of $2 \mathrm{mg} / \mathrm{L}$. At $96 \mathrm{~h}$, hypoxia significantly increased the deformity rate of larvae under $\mathrm{pH}$ 7.3.

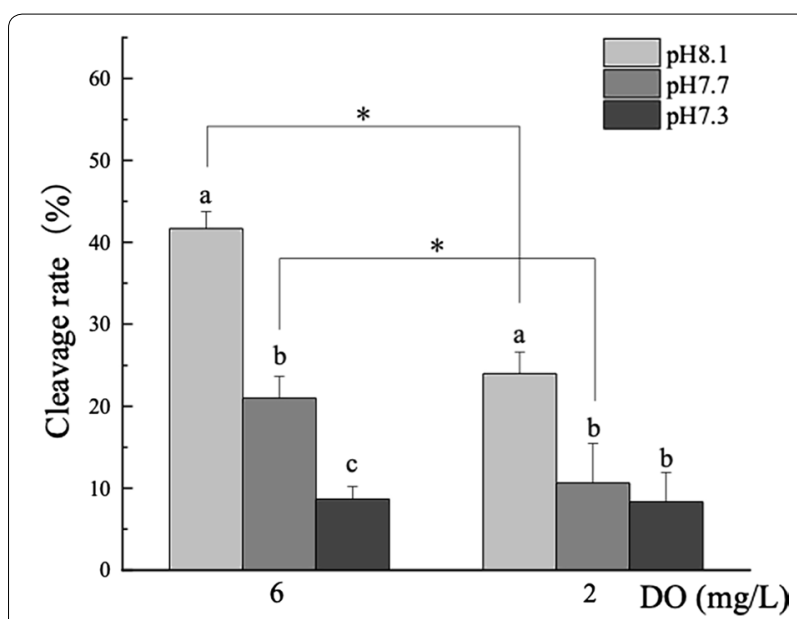

Fig. 3 The effects of different $\mathrm{pH}(8.1,7.7,7.3)$ and $\mathrm{DO}$ concentrations $(6 \mathrm{mg} / \mathrm{L}, 2 \mathrm{mg} / \mathrm{L}$ ) on the cleavage rate of mussels at $4 \mathrm{~h}$. Different lowercase letters represent significant differences between different pH under the same DO $(\mathrm{P}<0.05)$; ${ }^{*}$ indicates significant difference between different $\mathrm{DO}$ under the same $\mathrm{pH}$ conditions $(\mathrm{P}<0.05)$

Table 3 Summary of three-way ANOVA results on effects of $\mathrm{pH}$ and $\mathrm{DO}$ on deformity rate

\begin{tabular}{llrlll}
\hline \multicolumn{5}{l}{ Deformity rate } \\
\cline { 2 - 6 } & SS & df & MS & F & P \\
\hline$T$ & 60.719 & 2 & 30.360 & 16.005 & 0.000 \\
$\mathrm{DO}$ & 20.488 & 1 & 20.488 & 10.801 & 0.002 \\
$\mathrm{pH}$ & 1063.576 & 2 & 531.788 & 280.347 & 0.000 \\
$\mathrm{~T}^{*} \mathrm{DO}$ & 8.405 & 2 & 4.202 & 2.215 & 0.124 \\
$\mathrm{~T}^{*} \mathrm{pH}$ & 12.157 & 4 & 3.039 & 1.602 & 0.195 \\
$\mathrm{DO}{ }^{*} \mathrm{pH}$ & 8.687 & 2 & 4.343 & 2.290 & 0.116 \\
$\mathrm{~T}^{*} \mathrm{DO}{ }^{*} \mathrm{pH}$ & 0.421 & 4 & 0.105 & 0.056 & 0.994 \\
Error & 68.288 & 36 & 1.897 & & \\
Total & 21588.839 & 54 & & & \\
\hline
\end{tabular}




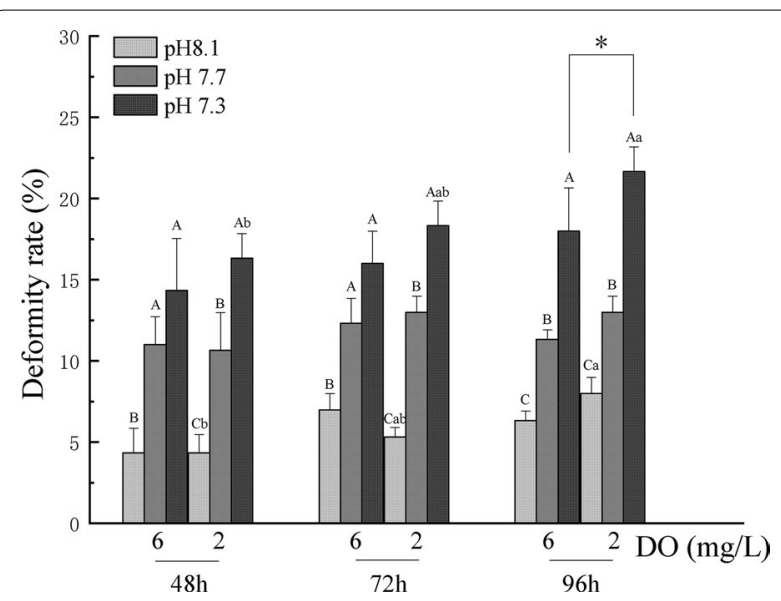

Fig. 4 The effect of different $\mathrm{pH}(8.1,7.7,7.3)$ and DO concentrations $(6 \mathrm{mg} / \mathrm{L}, 2 \mathrm{mg} / \mathrm{L})$ on the deformity rate of mussels during $96 \mathrm{~h}$ exposure. Different uppercase letters represent significant differences between different $\mathrm{pH}$ under the same $\mathrm{DO}(\mathrm{P}<0.05)$; different lowercase letters represent significant differences between different time points under the same $\mathrm{DO}$ and $\mathrm{pH}$ conditions $(\mathrm{P}<0.05)$; * indicates significant difference between different $\mathrm{DO}$ under the same pH conditions $(P<0.05)$

The shell length of D-shaped larvae was significantly affected $(\mathrm{P}<0.05)$ by $\mathrm{DO}$ and $\mathrm{pH}$ throughout the experiment; however, $\mathrm{DO}$ and $\mathrm{pH}$ did not have significant interaction on the shell length of $\mathrm{D}$-shaped larvae (Table 4, Fig. 5). At $24 \mathrm{~h}$ and $48 \mathrm{~h}, \mathrm{DO}$ and $\mathrm{pH}$ did not significantly affect the shell length of D-shaped larvae. From $72 \mathrm{~h}$, the growth of D-shaped larvae was significantly inhibited with the decrease in $\mathrm{pH}$. Among the four time points observed in the experiment, hypoxia was observed to significantly inhibit the shell length growth of the D-shaped larvae of mussels only at $96 \mathrm{~h}$ and under $\mathrm{pH} 7.3(\mathrm{P}<0.05)$.

The shell height of D-shaped larvae was significantly affected $(\mathrm{P}<0.05)$ by $\mathrm{DO}$ and $\mathrm{pH}$ throughout the experiment, but no significant interaction was found between DO and pH (Table 4, Fig. 6). At 24, 48, and $72 \mathrm{~h}$, no significant effect of acidification on the shell height of D-shaped larvae was observed under the two DO conditions. At 96 h, pH 7.3 significantly inhibited $(\mathrm{P}<0.05)$ shell height growth under both $\mathrm{DO}$ conditions. At $72 \mathrm{~h}$, hypoxia significantly inhibited $(\mathrm{P}<0.05)$ the increase in the shell height of D-shaped larvae under $\mathrm{pH} 8.1$ and $\mathrm{pH}$ 7.7. At $96 \mathrm{~h}$, hypoxia significantly inhibited $(\mathrm{P}<0.05)$ the increase in the shell height of $\mathrm{D}$-shaped larvae under the three $\mathrm{pH}$ conditions.

\section{Discussion}

Ocean acidification and hypoxia phenomena have frequently occurred in recent years, and the affected areas in marine environments are still expanding [43, 44].
Although the effects of acidification or hypoxia on marine organisms have been studied, most works are based on single factor effects; only a few focused on the combined stress of acidification and hypoxia on marine organisms [34, 45]. In practice, acidification and hypoxia occur simultaneously, thus highlighting the need to investigate the synergic effects of these two stressors [18-20]. In the present experiment, the effects of ocean acidification and hypoxia on the early development of the thick shell mussel were studied. The results showed that ocean acidification and hypoxia negatively affected the early development of the thick shell mussel. In addition, the synergistic effects of acidification and hypoxia on the cleavage rate of fertilized eggs and the deformation rate of mussel larvae were observed during the experiment.

Chemical changes in seawater affects every developmental stage in the life cycle of various marine organisms, and early development is the most sensitive stage [46-48]. Shi et al. [6] suggested that OA may affect the fertilization success of broadcast spawning bivalves by (1) reducing sperm swimming speed and therefore lowering the probability for gamete collision in 3D water column, (2) hampering the gamete recognition that results in constrained gamete fusion, and (3) interrupting the generation of $\mathrm{Ca}^{2+}$ oscillation that triggers cortical reaction and embryonic development. Swiezak et al. [49] explored the effect of acidification on fertilization and found that the fertilization rate of clam Limecola balthica was significantly reduced at low $\mathrm{pH}$. Similar to our experimental results, the fertilization rate of the thick shell mussel was significantly reduced at $\mathrm{pH}$ 7.3. We found that acidification and hypoxia significantly delayed the cleavage of fertilized eggs. Girard et al. [50] suggested that this phenomenon may be related to the interference of fertilized eggs on calcium homeostasis under ambient pressure. Moreover, acidification and hypoxia significantly increase the deformation rate when the fertilized eggs develop into larvae. When the $\mathrm{pH}$ of seawater is low, the deformation rate in early development of the undulated surf clam Paphia undulate significantly increases [51]. Possibly under seawater acidification, the early development stage of mussels is highly sensitive to elevated $\mathrm{pCO}_{2}$, thereby leading to failed larval shell mineralization [46, 52-54]. Segerstråle [55] showed that hypoxic conditions could result in bivalve shell deformities. Low DO significant increases the deformation rate of the early development of mussel Mytilus edulis, and acidification exacerbates this effect [15]. This finding is consistent with the results of our experiments and may have occurred because under adverse environmental conditions, marine invertebrates spend much energy coping with stress, thereby resulting in shell malformations due to the less energy allocated to shell growth $[56,57]$. 
Table 4 Summary of two-way ANOVA results on effects of pH and DO on larval shell length and shell height

\begin{tabular}{|c|c|c|c|c|c|c|}
\hline & & SS & df & MS & $F$ & $P$ \\
\hline \multicolumn{7}{|c|}{ Shell length } \\
\hline \multirow[t]{5}{*}{$48 \mathrm{~h}$} & DO & 150.222 & 1 & 150.222 & 1.777 & 0.207 \\
\hline & $\mathrm{pH}$ & 248.778 & 2 & 124.389 & 1.471 & 0.268 \\
\hline & $\mathrm{DO} * \mathrm{pH}$ & 17.444 & 2 & 8.722 & 0.103 & \\
\hline & Error & 1014.667 & 12 & 84.556 & & \\
\hline & Total & 164642.000 & 18 & & & \\
\hline \multirow[t]{5}{*}{$72 \mathrm{~h}$} & DO & 355.556 & 1 & 355.556 & 5.276 & 0.04 \\
\hline & $\mathrm{pH}$ & 445.444 & 2 & 222.722 & 3.305 & 0.072 \\
\hline & $\mathrm{DO} * \mathrm{pH}$ & 15.444 & 2 & 7.722 & 0.115 & 0.893 \\
\hline & Error & 808.667 & 12 & 67.389 & & \\
\hline & Total & 180826.000 & 18 & & & \\
\hline \multirow[t]{5}{*}{$96 \mathrm{~h}$} & DO & 138.889 & 1 & 138.889 & 4.762 & 0.050 \\
\hline & $\mathrm{pH}$ & 1552.111 & 2 & 776.056 & 26.608 & 0.000 \\
\hline & $\mathrm{DO} * \mathrm{pH}$ & 22.111 & 2 & 11.056 & 0.379 & 0.692 \\
\hline & Error & 350.000 & 12 & 29.167 & & \\
\hline & Total & 209002.000 & 18 & & & \\
\hline \multicolumn{7}{|c|}{ Shell height } \\
\hline \multirow[t]{5}{*}{$48 \mathrm{~h}$} & DO & 88.889 & 1 & 88.889 & 1.752 & 0.210 \\
\hline & $\mathrm{pH}$ & 125.778 & 2 & 62.889 & 1.240 & 0.324 \\
\hline & $\mathrm{DO} * \mathrm{pH}$ & 7.111 & 2 & 3.556 & 0.070 & 0.933 \\
\hline & Error & 608.667 & 12 & 50.722 & & \\
\hline & Total & 92994.000 & 18 & & & \\
\hline \multirow[t]{5}{*}{$72 \mathrm{~h}$} & DO & 272.222 & 1 & 272.222 & 6.110 & 0.029 \\
\hline & $\mathrm{pH}$ & 271.444 & 2 & 135.722 & 3.046 & 0.085 \\
\hline & $\mathrm{DO} * \mathrm{pH}$ & 15.444 & 2 & 7.722 & 0.173 & 0.843 \\
\hline & Error & 534.667 & 12 & 44.556 & & \\
\hline & Total & 104758.000 & 18 & & & \\
\hline \multirow[t]{5}{*}{$96 \mathrm{~h}$} & DO & 213.556 & 1 & 213.556 & 24.484 & 0.000 \\
\hline & $\mathrm{pH}$ & 688.000 & 2 & 344.000 & 39.439 & 0.000 \\
\hline & $\mathrm{DO} * \mathrm{pH}$ & 13.778 & 2 & 6.889 & 0.790 & 0.476 \\
\hline & Error & 104.667 & 12 & 8.722 & & \\
\hline & Total & 119118.000 & 18 & & & \\
\hline
\end{tabular}

During mussel larval growth, acidification and hypoxia significantly inhibited the growth of larval shells, and this effect was strengthened over time. Young and Gobler [58] studied the effects of ocean acidification on eastern oyster Crassostrea virginica and found that the growth rate of oyster shells is significantly reduced by low $\mathrm{pH}$ due to the dissolution of calcium carbonate, the main component of the shell, under acidification conditions [59, 60]. Under acidification conditions, the shellfish consumes much energy to fight against environmental stress (such as acidbase regulation), resulting in a decrease in energy allocated for growth [61-64]. Dorey et al. [64] studied the effects of low $\mathrm{pH}$ on the larvae of green sea urchin Strongylocentrotus droebachiensis and found that low $\mathrm{pH}$ significantly increases their respiration rate, indicating that a decrease in $\mathrm{pH}$ would increase the body's energy consumption. With regard to acidification, shellfish in the absence of oxygen also reduce their energy allocated for growth due to external pressure, resulting in growth inhibition [34, 56, 57]. In the present experiment, acidification additionally consumed a part of the energy used for body growth, and anti-hypoxia increased the energy consumption of this part. Therefore, acidification significantly inhibited the growth of mussel larvae, and hypoxia aggravated this effect. Shellfish exposed to hypoxia undergo anaerobic respiration and exert great resistance to external stress $[65,66]$, but this adaptive response is only short-term. Although the short-term acidification and hypoxia stress in this experiment only led to growth inhibition and did not cause death, a long-term exposure to such 


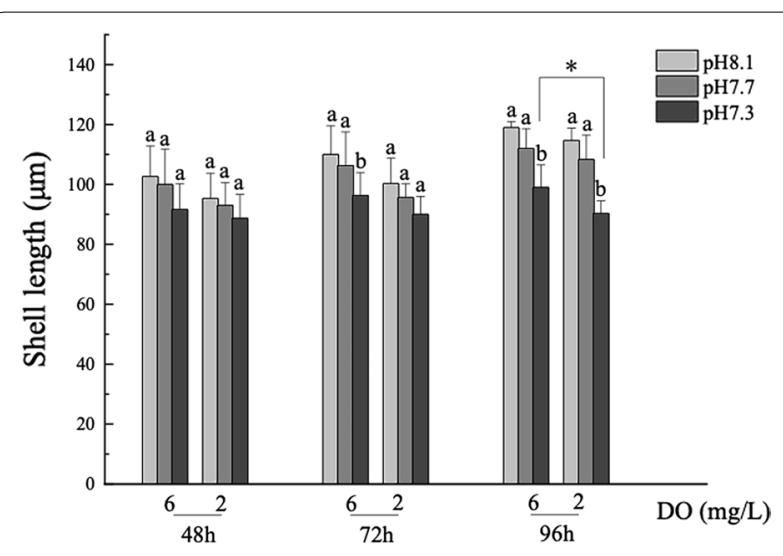

Fig. 5 The effect of different $\mathrm{pH}(8.1,7.7,7.3)$ and DO concentrations $(6 \mathrm{mg} / \mathrm{L}, 2 \mathrm{mg} / \mathrm{L})$ on the shell length of larvae of mussels during $96 \mathrm{~h}$ exposure. Different lowercase letters represent significant differences between different $\mathrm{pH}$ under the same $\mathrm{DO}(\mathrm{P}<0.05)$; ${ }^{*}$ indicates significant difference between different $\mathrm{DO}$ under the same $\mathrm{pH}$ conditions $(P<0.05)$

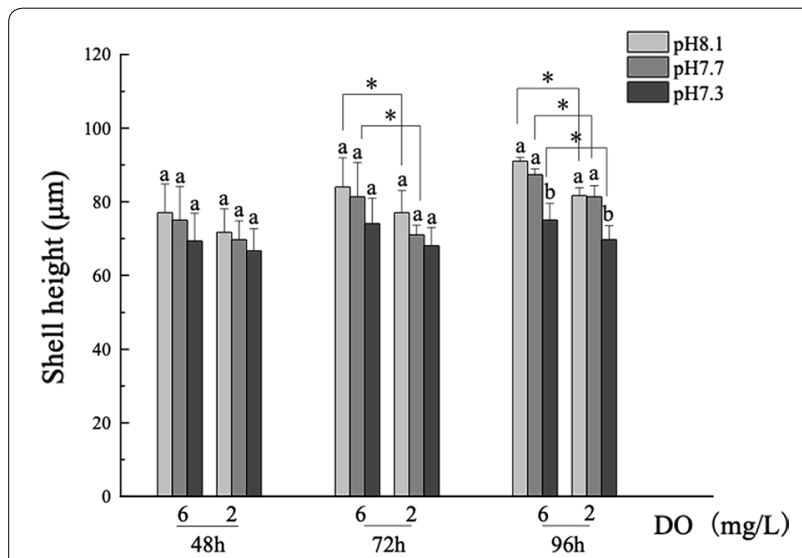

Fig. 6 The effect of different $\mathrm{pH}(8.1,7.7,7.3)$ and DO concentrations $(6 \mathrm{mg} / \mathrm{L}, 2 \mathrm{mg} / \mathrm{L})$ on the shell height of mussels during $96 \mathrm{~h}$ exposure. Different lowercase letters represent significant differences between different $\mathrm{pH}$ under the same $\mathrm{DO}(\mathrm{P}<0.05) ;{ }^{*}$ indicates significant difference between different $\mathrm{DO}$ under the same $\mathrm{pH}$ conditions $(P<0.05)$

environmental stress may threaten the survival and even lead to death $[57,67]$. Therefore, long exposures are necessary in studying the impact of acidification and hypoxia on marine mussels.

\section{Conclusion}

This experiment investigated the combined effects of acidification and hypoxia on the early development of the thick shell mussel $M$. coruscus. Results showed that hypoxia had no effect on fertilization rate. Acidification and hypoxia had significant negative effects on the various stages of early development of the thick shell mussel and showed significant interactive influences on the cleavage rate of fertilized eggs and the deformation rate of mussel larvae during the experiment. Although the short-term exposure test has not resulted in mussel death, the effects of long-term exposure to these two environmental stresses need further study.

\section{Acknowledgements \\ We are grateful to two anonymous reviewers who helped to improve the manuscript.}

\section{Authors' contributions}

$\mathrm{MH}, J Y, Y W$ and $Y D$ conceived the study, $X W$ and YS carried out the experiment, HK and YS analyzed the data, XW wrote the manuscript. All authors read and approved the final manuscript.

\section{Funding}

The authors acknowledge funding from the research Grant $(31,872,587)$ from the Natural Science Foundation of China, the Shanghai Pujiang Talent Program (18PJ1404000), a Grant from Shanghai Municipal Natural Science Foundation (17ZR1412900). This work was also supported by Guangdong South China Sea Key Laboratory of Aquaculture for Aquatic Economic Animals, Guangdong Ocean University (KFKT2019ZD04) and the Open Fund of Shandong Key Laboratory of Disease Control in Mariculture (KF201802).

\section{Ethics approval and consent to participate}

All applicable international, national, and/or institutional guidelines for the care and use of animals were followed.

\section{Consent for publication}

Not applicable.

\section{Competing interests}

The authors declare that they have no competing interests.

\section{Author details}

${ }^{1}$ Fisheries College, Guangdong Ocean University, Zhanjiang 524088, China.

2 International Research Center for Marine Biosciences, Shanghai Ocean University, Ministry of Science and Technology, Shanghai 201306, China.

${ }^{3}$ Key Laboratory of Exploration and Utilization of Aquatic Genetic Resources, Ministry of Education, Shanghai Ocean University, 999 Huchenghuan Road, Shanghai 201306, China.

Received: 10 October 2019 Accepted: 7 January 2020

Published online: 24 January 2020

\section{References}

1. Caldeira K, Wickett ME. Anthropogenic carbon and ocean pH. Nature. 2003:425:365-365.

2. Feely RA, Sabine CL, Lee K, Berelson W, Kleypas J, Fabry VJ, Millero FJ. Impact of anthropogenic $\mathrm{CO}_{2}$ on the $\mathrm{CaCO}_{3}$ system in the oceans. Science. 2004;305:362-6.

3. Sabine CL, Feely RA, Gruber N, Key RM, Lee K, Bullister JL, Wanninkhof R, Wong CS, Wallace DWR, Tilbrook B, Millero FJ, Peng TH, Kozyr $\mathrm{A}$, Ono T, Rios AF. The oceanic sink for anthropogenic $\mathrm{CO}_{2}$. Science. 2004;305:367-71.

4. Caldeira K, Wickett ME. Ocean model predictions of chemistry changes from carbon dioxide emissions to the atmosphere and ocean. J Geophys Res-Oceans. 2005. https://doi.org/10.1029/2004JC002671.

5. Orr JC, Fabry VJ, Aumont O, Bopp L, Doney SC, Feely RA, Gnanadesikan A, Gruber N, Ishida A, Joos F, Key RM, Lindsay K, Maier-Reimer E, Matear R, Monfray P, Mouchet A, Najjar RG, Plattner GK, Rodgers KB, Sabine CL, Sarmiento JL, Schlitzer R, Slater RD, Totterdell IJ, Weirig MF, Yamanaka Y, 
Yool A. Anthropogenic ocean acidification over the twenty-first century and its impact on calcifying organisms. Nature. 2005;437:681-6.

6. Shi W, Han Y, Guo C, Zhao X, Liu S, Su W, Wan Y, Zha S, Chai X, Liu G. Ocean acidification hampers sperm-egg collisions, gamete fusion, and generation of $\mathrm{Ca}^{2+}$ oscillations of a broadcast spawning bivalve. Tegillarca granosa. Mar Environ Res. 2017;130:106-12.

7. Zhao X, Shi W, Han Y, Liu S, Guo C, Fu W, Chai X, Liu G. Ocean acidification adversely influences metabolism, extracellular pH and calcification of an economically important marine bivalve Tegillarca granosa. Mar Environ Res. 2017;125:82-9.

8. Peng C, Zhao X, Liu S, Shi W, Han Y, Guo C, Peng X, Chai X, Liu G. Ocean acidification alters the burrowing behaviour, $\mathrm{Ca}^{2+} / \mathrm{Mg}^{2+}$-ATPase activity, metabolism, and gene expression of a bivalve species Sinonovacula constricta. Mar Ecol Prog Ser. 2017;575:107-17.

9. Rong J, Su W, Guan X, Shi W, Zha S, He M, Wang H, Liu G. Ocean acidification impairs foraging behavior by interfering with olfactory neural signal transduction in black sea bream Acanthopagrus schlegelii. Front Physiol. 2018:9:1592.

10. Zhao X, Guo C, Han Y, Che Z, Wang Y, Wang X, Chai X, Wu H, Liu G. Ocean acidification decreases mussel byssal attachment strength and induces molecular byssal responses. Mar Ecol Prog Ser. 2017;565:67-77.

11. Su W, Rong J, Zha S, Yan M, Fang J, Liu G. Ocean acidification affects the cytoskeleton, lysozymes, and nitric oxide of hemocytes: a possible explanation for the hampered phagocytosis in blood clams Tegillarca granosa. Front Physiol. 2018;9:619.

12. Dodd LF, Grabowski JH, Piehler MF, Westfield I, Ries JB. Ocean acidification impairs crab foraging behaviour. Proc R Soc B Biol Sci. 2015;282:20150333.

13. Zeng $X$, Chen $X$, Zhuang J. The positive relationship between ocean acidification and pollution. Mar Pollut Bull. 2015;91:14-21.

14. Hoshijima U, Hofmann GE. Variability of seawater chemistry in a kelp forest environment is linked to in situ transgenerational effects in the purple sea urchin Strongylocentrotus purpuratus. Front Mar Sci. 2019;6:62.

15. Kong $H$, Jiang $X$, Clements JC, Wang $T$, Huang $X$, Shang $Y$, Chen J, Hu M, Wang $Y$. Transgenerational effects of short-term exposure to acidification and hypoxia on early developmental traits of the mussel Mytilus edulis. Mar Environ Res. 2019;145:73-80.

16. Guo X, Huang M, Pu F, You W, Ke C. Effects of ocean acidification caused by rising $\mathrm{CO}_{2}$ on the early development of three mollusks. Aquat Biol. 2015;23:147-57.

17. Kapsenberg L, Miglioli A, Bitter MC, Tambutte E, Dumollard R, Gattuso JP. Ocean pH fluctuations affect mussel larvae at key developmental transitions. Proc Biol Sci. 2018:285:20182381.

18. Feely RA, Alin SR, Newton J, Sabine CL, Warner M, Devol A, Krembs C, Maloy $C$. The combined effects of ocean acidification, mixing, and respiration on $\mathrm{pH}$ and carbonate saturation in an urbanized estuary. Estuar Coast Shelf Sci. 2010;88:442-9.

19. Cai WJ, Hu X, Huang WJ, Murrell MC, Lehrter JC, Lohrenz SE, Chou WC, Zhai W, Hollibaugh JT, Wang Y, Zhao P, Guo X, Gundersen K, Dai M, Gong $\mathrm{G}-\mathrm{C}$. Acidification of subsurface coastal waters enhanced by eutrophication. Nat Geosci. 2011;4:766-70.

20. Melzner F, Thomsen J, Koeve W, Oschlies A, Gutowska MA, Bange HW, Hansen HP, Koertzinger A. Future ocean acidification will be amplified by hypoxia in coastal habitats. Mar Biol. 2013;160:1875-88.

21. Wallace RB, Baumann H, Grear JS, Aller RC, Gobler CJ. Coastal ocean acidification: the other eutrophication problem. Estuar Coast Shelf Sci. 2014;148:1-13.

22. Baumann $\mathrm{H}$, Wallace RB, Tagliaferri $\mathrm{T}$, Gobler CJ. Large natural $\mathrm{pH}, \mathrm{CO}_{2}$ and $\mathrm{O}_{2}$ fluctuations in a temperate tidal salt marsh on diel, seasonal, and interannual time scales. Estuaries Coasts. 2015;38:220-31.

23. Wei H, He Y, Li Q, Liu Z, Wang H. Summer hypoxia adjacent to the Changjiang Estuary. J Mar Syst. 2007;67:292-303.

24. Fabry VJ, Seibel BA, Feely RA, Orr JC. Impacts of ocean acidification on marine fauna and ecosystem processes. ICES J Mar Sci. 2008;65:414-32.

25. Gobler CJ, Baumann H. Hypoxia and acidification in ocean ecosystems: coupled dynamics and effects on marine life. Biol Lett. 2016;12:20150976.

26. Diaz RJ, Rosenberg R. Spreading dead zones and consequences for marine ecosystems. Science. 2008;321:926-9.

27. Vaquer-Sunyer R, Duarte CM. Thresholds of hypoxia for marine biodiversity. Proc Natl Acad Sci U. S. A. 2008;105:15452-7.

28. Keeling RF, Koertzinger A, Gruber N. Ocean deoxygenation in a warming world. Annu Rev Mar Sci. 2010;2:199-229.
29. Clark HR, Gobler CJ. Diurnal fluctuations in $\mathrm{CO}_{2}$ and dissolved oxygen concentrations do not provide a refuge from hypoxia and acidification for early-life-stage bivalves. Mar Ecol Prog Ser. 2016;558:1-14.

30. Beliaeff B, Oconnor TP, Daskalakis DK, Smith PJ. US Mussel Watch data from 1986 to 1994: temporal trend detection at large spatial scales. Environ Sci Technol. 1997;31:1411-5.

31. Fischer J, Phillips NE. Carry-over effects of multiple stressors on benthic embryos are mediated by larval exposure to elevated UVB and temperature. Global Change Biol. 2014;20:2108-16.

32. Hettinger A, Sanford E, Hill TM, Lenz EA, Russell AD, Gaylord B. Larval carry-over effects from ocean acidification persist in the natural environment. Global Change Biol. 2013;19:3317-26.

33. Stevens AM, Gobler CJ. Interactive effects of acidification, hypoxia, and thermal stress on growth, respiration, and survival of four North Atlantic bivalves. Mar Ecol Prog Ser. 2018;604:143-61.

34. Gobler CJ, DePasquale EL, Griffith AW, Baumann H. Hypoxia and acidification have additive and synergistic negative effects on the growth, survival, and metamorphosis of early life stage bivalves. PLOS ONE. 2014;9:e83648.

35. Meadows PS, Meadows A, Murray JMH. Biological modifiers of marine benthic seascapes: their role as ecosystem engineers. Geomorphology. 2012;157:31-48.

36. Liao Z, Wang XC, Liu HH, Fan MH, Sun JJ, Shen W. Molecular characterization of a novel antimicrobial peptide from Mytilus coruscus. Fish Shellfish Immunol. 2013;34:610-6.

37. Sui Y, Liu Y, Zhao X, Dupont S, Hu M, Wu F, Huang X, Li J, Lu W, Wang Y. Defense responses to short-term hypoxia and seawater acidification in the thick shell mussel Mytilus coruscus. Front Physiol. 2017;8:145.

38. Guo C, Han Y, Shi W, Zhao X, Teng S, Xiao G, Yan M, Chai X, Liu G. $\mathrm{Ca}^{2+}$-channel and calmodulin play crucial roles in the fast electrical polyspermy blocking of Tegillarca granosa (Bivalvia: Arcidae). J Molluscan Stud. 2017;83:289-94.

39. Liu G, Innes D, Thompson RJ. Quantitative analysis of sperm plane circular movement in the blue mussels Mytilus edulis, M. trossulus and their hybrids. J Exp Zool Part A. 2011;315A:280-90.

40. Wu F, Cui S, Sun M, Xie Z, Huang W, Huang X, Liu L, Hu M, Lu W, Wang Y. Combined effects of ZnO NPs and seawater acidification on the haemocyte parameters of thick shell mussel Mytilus coruscus. Sci Total Environ. 2018;624:820-30

41. Sui Y, Hu M, Huang X, Wang Y, Lu W. Anti-predatory responses of the thick shell mussel Mytilus coruscus exposed to seawater acidification and hypoxia. Mar Environ Res. 2015;109:159-67.

42. Lewis C, Clemow K, Holt WV. Metal contamination increases the sensitivity of larvae but not gametes to ocean acidification in the polychaete Pomatoceros lamarckii (Quatrefages). Mar Biol. 2013;160:2089-101.

43. Gruber N. Warming up, turning sour, losing breath: ocean biogeochemistry under global change. Proc R Soc A-Math Phys Eng Sci. 2011;369:1980-96.

44. Doney SC, Ruckelshaus M, Duffy JE, Barry JP, Chan F, English CA, Galindo HM, Grebmeier JM, Hollowed AB, Knowlton N, Polovina J, Rabalais NN, Sydeman WJ, Talley LD. Climate change impacts on marine ecosystems. Annu Rev Mar Sci. 2012;4:11-37.

45. DePasquale E, Baumann H, Gobler CJ. Vulnerability of early life stage Northwest Atlantic forage fish to ocean acidification and low oxygen. Mar Ecol Prog Ser. 2015;523:145-56.

46. Kurihara $\mathrm{H}$. Effects of $\mathrm{CO}_{2}$-driven ocean acidification on the early developmental stages of invertebrates. Mar Ecol-Prog Ser. 2008;373:275-84.

47. Talmage SC, Gobler CJ. Effects of past, present, and future ocean carbon dioxide concentrations on the growth and survival of larval shellfish. Proc Natl Acad Sci U. S. A. 2010;107:17246-51.

48. Gazeau F, Parker LM, Comeau S, Gattuso J-P, O'Connor WA, Martin S, Pörtner H-O, Ross PM. Impacts of ocean acidification on marine shelled molluscs. Mar Biol. 2013;160:2207-45.

49. Swiezak J, Borrero-Santiago AR, Sokolowski A, Olsen AJ. Impact of environmental hypercapnia on fertilization success rate and the early embryonic development of the clam Limecola balthica (Bivalvia, Tellinidae) from the southern Baltic Sea-a potential $\mathrm{CO}_{2}$ leakage case study. Mar Pollut Bull. 2018;136:201-11.

50. Girard JP, Graillet C, Pesando D, Payan P. Calcium homeostasis and early embryotoxicity in marine invertebrates. Comp Biochem Physiol Pt C. 1996;113:169-75. 
51. Guo X, Xu X, Zhang P, Huang M, Luo X, You W, Ke C. Early development of undulated surf clam, Paphia undulate under elevated pCO(2). J Exp Mar Biol Ecol. 2016;484:23-30.

52. Kurihara $\mathrm{H}$, Kato $\mathrm{S}$, Ishimatsu A. Effects of increased seawater $\mathrm{pCO}(2)$ on early development of the oyster Crassostrea gigas. Aquat Biol. 2007;1:91-8.

53. Parker LM, Ross PM, O'Connor WA. The effect of ocean acidification and temperature on the fertilization and embryonic development of the Sydney rock oyster Saccostrea glomerata (Gould 1850). Global Change Biol. 2009;15:2123-36.

54. Parker LM, Ross PM, O'Connor WA. Comparing the effect of elevated $\mathrm{pCO}(2)$ and temperature on the fertilization and early development of two species of oysters. Mar Biol. 2010;157:2435-52.

55. Segerstråle SG. Investigations on Baltic populations of the bivalve Macoma balthica (L.). Comment Soc Sci Fenn Biol. 1960;23:1-72.

56. Pörtner HO, Langenbuch M, Michaelidis B. Synergistic effects of temperature extremes, hypoxia, and increases in $\mathrm{CO}_{2}$ on marine animals: from earth history to global change. J Geophys Res-Oceans. 2005. https://doi. org/10.1029/2004JC002561.

57. Sokolova IM. Energy-limited tolerance to stress as a conceptual framework to integrate the effects of multiple stressors. Integr Comp Biol. 2013:53:597-608.

58. Young CS, Gobler CJ. The ability of macroalgae to mitigate the negative effects of ocean acidification on four species of North Atlantic bivalve. Biogeosciences. 2018;15:6167-83.

59. Kleypas JA, Buddemeier RW, Archer D, Gattuso JP, Langdon C, Opdyke BN Geochemical consequences of increased atmospheric carbon dioxide on coral reefs. Science. 1999;284:118-20.

60. Findlay HS, Kendall MA, Spicer Jl, Widdicombe S. Future high $\mathrm{CO}_{2}$ in the intertidal may compromise adult barnacle Semibalanus balanoides survival and embryonic development rate. Mar Ecol Prog Ser 2009;389:193-202.
61. Stumpp M, Wren J, Melzner F, Thorndyke MC, Dupont ST. CO ${ }_{2}$ induced seawater acidification impacts sea urchin larval development I: elevated metabolic rates decrease scope for growth and induce developmental delay. Comp Biochem Physiol A—Mol Integr Physiol. 2011;160:331-40.

62. Stumpp M, Hu MY, Melzner F, Gutowska MA, Dorey N, Himmerkus N, Holtmann WC, Dupont ST, Thorndyke MC, Bleich M. Acidified seawater impacts sea urchin larvae $\mathrm{pH}$ regulatory systems relevant for calcification. Proc Natl Acad Sci U. S. A. 2012;109:18192-7.

63. Stumpp M, Hu M, Casties I, Saborowski R, Bleich M, Melzner F, Dupont S. Digestion in sea urchin larvae impaired under ocean acidification. Nat Clim Chang. 2013;3:1044-9.

64. Dorey N, Lancon P, Thorndyke M, Dupont S. Assessing physiological tipping point of sea urchin larvae exposed to a broad range of $\mathrm{pH}$. Global Change Biol. 2013;19:3355-67.

65. Hochachka PW, Lutz PL. Mechanism, origin, and evolution of anoxia tolerance in animals. Comp Biochem Physiol B-Biochem Mol Biol. 2001;130:435-59.

66. Wu RSS. Hypoxia: from molecular responses to ecosystem responses. Mar Pollut Bull. 2002;45:35-45.

67. Pörtner HO. Oxygen- and capacity-limitation of thermal tolerance: a matrix for integrating climate-related stressor effects in marine ecosystems. J Exp Biol. 2010;213:881-93.

\section{Publisher's Note}

Springer Nature remains neutral with regard to jurisdictional claims in published maps and institutional affiliations.
Ready to submit your research? Choose BMC and benefit from:

- fast, convenient online submission

- thorough peer review by experienced researchers in your field

- rapid publication on acceptance

- support for research data, including large and complex data types

- gold Open Access which fosters wider collaboration and increased citations

- maximum visibility for your research: over $100 \mathrm{M}$ website views per year

At $\mathrm{BMC}$, research is always in progress.

Learn more biomedcentral.com/submissions 